\title{
The Association of Human Cytomegalovirus Infection of Male Genital Tract and Male Infertility
}

\author{
Ahmed Sahib Abdulamir ${ }^{a}$ Salah Mahdi hassen ${ }^{b}$ \\ ${ }^{a}$ University of Al-Nahrain, College of Medicine, Microbiology department \\ ${ }^{b}$ Medical technical university, College of health and medical Technology, Department of medical \\ lab.Technology,Baghdad.
}

drnihadkhalawe@gmail.com

Submission date:- 7/3/2018 Acceptance date:- 4/4/2018 Publication date:- 14/10/2018

Keywords: Viruses, masculine males, male reproductive system.

\begin{abstract}
Background: The human cytomegalovirus (HCMV) is a widely distributed virus among humans and is included within the sexually transmitted viruses. Because its low detection rate in semen, the impact of HCMV on sperm formation and its vertical transmission within the sperm cells has not been studied sufficiently.

Objectives: To investigate the association of viral infections present in the lower genital tract of males and relationship among males infertility.

Methods: ELISA and RT-PCR technique of 100 semen and serum specimens, collected over 8 months from males investigated for infertility, were retrospectively assessed, by screening anti-human Herpes Simplex Virus (HCMV) $\operatorname{IgM}$ and $\mathrm{IgG}$ in the serum and detection of HSV DNA in seminal fluid.

Results: One hundred seminal fluid and blood samples were taken from men and investigated for infertility over a period of 8 months from July 2016 to February 2017. The seminal fluids and serum of patients mentioned to the laboratory from the fertility clinics of Kamal AL-samarai hospital and outer clinics. The investigations were conducted to find the HCMV detection rate in the seminal fluid of infertile men and to evaluate the impact of the viral infection on the major sperm parameters. Blood and seminal fluid were collected from 100 infertile males. The results were shown that $24 / 100(24.0 \%)$ were positive for $\operatorname{IgM}$ and $86 / 100(86.0 \%)$ were positive for $\operatorname{IgG}$ of HCMV. In case of control group, results were (1.0\%) positive for anti-HCMV IgM antibodies, while (20.0\%) positive for anti-HCMV IgG antibodies in control group, using ELISA test.
\end{abstract}

The PCR showed that out of 100 samples 24 (24.0\%) gave positive results for HCMV patients, while 7 (7.0\%) positive for HCMV in control group.

Conclusions: Using sensitive procedures for assays, seminal samples of asymptomatic infertile patients showed unexpectedly high incidence of the sexually transmitted pathogens.

\section{1- Introduction}

In the reproductive medicine field, the sexually transmitted infections (STIs) are of major concern to researchers and doctors. Many STI pathogens usually cause incurable and even fatal diseases, and have been shown to be transmitted via insemination procedures (1). Furthermore, many of these pathogenic microorganisms can be transmitted from infected mothers to their fetuses or children (2). Over time, men can also harbor the subclinical infection in their genital tract. Many viruses, such as cytomegalovirus (CMV) and herpes simplex virus type 2 (HSV-2) were detected in the seminal fluid of asymptomatic men (3). The importance of genital tract pathogens as causative factors of male infertility is still a controversial topics. This study aims to determine the prevalence of many commonly sexually transmitted pathogens in healthy and infertile male persons (4). Like other herpesviruses, after primary infection HCMV has the ability to establish latency in various different types of cells (5). HCMV infection may occur in individual without prior exposure to the virus (primary infection), or in those with previous exposure (recurrent infection) (6). Primary or recurrent infection (active infection) may be asymptomatic or cause mild or sever illness (7). HCMV circulate worldwide without seasonal variation and commonly infects people of all ages, races, and those from a variety of socioeconomic, cultural, and geographic 
backgrounds (8). Seroprevalence of HCMV in developing countries is higher than seroprevalence in developed countries (9). HCMV viruses have been isolated from oropharyngeal secretions, stool, urine, seminal fluid, blood, cervical \& vaginal secretions as well as milk (10). The virus can be discharged in the seminal fluid before coming into contact with the sperms during its presence in the accessory glands. The presence of these viruses in the seminal fluid indicates a genital tract infection, and the seminal fluid can be a viral propagation vector $(11,12)$. CMV is the leading cause (up to 10\%) of neonatal deaths in Iraq (13), In the current study, HCMV was the target of investigation in order to elucidate any relationship between this virus infection of genital tract and idiopathic male infertility.

\section{2- Materials and methods}

One hundred seminal fluid and serum specimens from infertile men attending Kamal AL-Samarai hospital were investigated for infertility and 100 fertile men as a control group were collected over a period from July 2016 to February 2017 were analyzed. ELISA technique was used to measure anti-HCMV IgM and IgG antibodies ( Human, Gesellschaft for Biochemical and diagnostical mbH, Germany).

After (3-5) days of sexual abstinence, semen samples were collected in the laboratory by masturbation. The ejaculate was deposited in sterile wide mouth, screw capped, and plastic container. The seminal fluid was examined according to world health organization (WHO) 2010 criteria of seminal fluid. The ejaculate was deposited in s sterile wide mouth, screw capped, and plastic container. The seminal fluid examination included ejaculate $\mathrm{pH}$, volume, viscosity and sperm concentration in (millions / $\mathrm{ml}$ ), which have been determined by using the Makler Chamber, while sperm motility has been determined as motile spermatozoa percentage, and morphology as percentage of sperms with normal shapes. Measuring of the ejaculate volume was performed by placing the whole specimen in a graduated pipette, and measurement of the total sperm count was done by multiplying the ejaculate volume by the sperm concentration. To study the morphology of sperms, seminal smears were put on slides, and allowed for drying at room temperature, then stained with eosin and in accordance with WHO criteria, they were examined for normal or abnormal sperm morphology(14). Using a light microscope, motility of sperms was examined after putting a drop of semen on a slide and evaluation of 100 sperms in each specimen. Sperm motility was defined pursuant to the World Health Organization as the following: type 1 (fast sperms with straight forward motility); type 2 (fast sluggish moving sperms); type 3 (locally shaking sperms); and type 4 (immotile or non-motile sperms)(14).

The reference points of a normal seminal fluid were reported in accordance with the WHO criteria as: Sperm concentration ( $\geq 20$ millions sperms $/ \mathrm{ml}$ ), morphology ( $\geq 30 \%$ sperms), motility ( $\geq 50 \%$ sperms with forward motility category a and $b$ or $\geq 25 \%$ sperms with category a)(14).

The seminal fluid samples with abnormal results were examined on two different occasions at eight week intervals. The average of the two readings was estimated. All samples were tested for the presence of HCMV DNA by real-time PCR method (genetic PCR solutions ${ }^{\mathrm{TM},}$, spain). Real time PCR instrument used in this work was STRATAGENE MxPro QPCR (Agilent Technologies, USA). The thermal protocol for HCMV dtec- qPCR Test F100/F300 format Kit is composed of an initial denaturation for activation the HotStarTaq DNA Polymerase, amplification cycle and a terminal hold as shown in table (1). The real-time data is collected at the second step of the amplification cycle. Before starting a Real-Time PCR reaction, the following steps were completed: Choosing the correct filters (FAM) Identifying and labeling of unknown samples, standards, positiveand negative controls, and assigning the quantitative values for the standards. The correct thermal protocol selected.

Table (1): Human cytomegalovirus real time PCR amplification profile

\begin{tabular}{|c|c|c|c|}
\hline \multicolumn{2}{|c|}{$\begin{array}{ll}\text { Step } \\
\end{array}$} & Time & Temperature \\
\hline \multicolumn{2}{|r|}{ Activation $^{1}$} & $15 \mathrm{~min}$ & $95^{\circ} \mathrm{c}$ \\
\hline \multirow[b]{2}{*}{ \& $\frac{3}{0}$} & Denaturation & $15 \mathrm{sec}$ & $95^{\circ} \mathrm{c}$ \\
\hline & $\begin{array}{l}\text { Hybridization / Extension and data } \\
\text { collection }^{2}\end{array}$ & $60 \mathrm{sec}$ & $60^{\circ} \mathrm{c}$ \\
\hline
\end{tabular}

In order to avoid sample to sample contamination and PCR product carryover, standard precautions were taken. DNA was extracted from HMCV strain, and infected Vero cells were used as positive controls, while a mixture without DNA template served as a negative control. 


\section{3- Results}

In the present study, the principal finding was the age, which ranged between 20-50 years. The highest prevalence of infection was age 26-30 years than other age classes. The lowest prevalence of infection was at age 45-50 year, statistical analysis showed there were significant difference $(\mathrm{P}$ value $=0.043)$ in distribution of genital tract infections among age groups as shown in table (2).

Table (2) Age descriptive data among study groups

\begin{tabular}{|c|c|c|}
\hline \multirow[t]{2}{*}{ Age groups } & \multicolumn{2}{|c|}{ Group } \\
\hline & Patients & Control \\
\hline$<=25$ years & 30 & 26 \\
\hline$\%$ & $30.0 \%$ & $26.0 \%$ \\
\hline $26-30$ years & 39 & 50 \\
\hline$\%$ & $39.0 \%$ & $50.0 \%$ \\
\hline $31-40$ years & 19 & 22 \\
\hline$\%$ & $19.0 \%$ & $22.0 \%$ \\
\hline $41-45$ years & 6 & 2 \\
\hline$\%$ & $6.0 \%$ & $2.0 \%$ \\
\hline$>45$ years & 6 & 0 \\
\hline$\%$ & $6.0 \%$ & $0.0 \%$ \\
\hline \multirow[t]{2}{*}{ Total } & 100 & 100 \\
\hline & $100.0 \%$ & $100.0 \%$ \\
\hline $\mathrm{p}$ value & 0.043 & \\
\hline
\end{tabular}

No similar seropositivite results regarding anti-CMV IgM and IgG antibodies were found in both patient men and controls. There was a significant association $(\mathrm{p}<0.05)$ between infertility and the high levels of anti-CMV IgG and $\operatorname{IgM}$ antibodies, as shown in tables (3) and (4).

The current study revealed that the seroprevalence of anti-CMV IgM and IgG was $24(24.0 \%)$ and $86(86 \%)$ antibodies in infertile patients respectively, tables 1 and 2, and was compared with fertile control antibody 1 $(1.0 \%)$ for IgM and $20(20.0 \%)$ for IgG. The relative risk (RR) for having male infertility was 2.21 and 5.45 for positive HCMV IgM and IgG, respectively $(\mathrm{P}<0.05)$.

Table (3): Identification of HCMV (IgM) Ab from infertile and control groups by ELISA technique.

\begin{tabular}{|c|c|c|c|c|c|c|}
\hline & & & \multicolumn{2}{|c|}{ Group } & \multirow{2}{*}{$p$ value } & \multirow{2}{*}{ RR (CI) } \\
\hline & & & Patients & Control & & \\
\hline \multirow{4}{*}{ CMV IgM } & \multirow{2}{*}{ Positive } & Count & 24 & 1 & \multirow{6}{*}{0.001} & \multirow{6}{*}{$2.21(1.83-2.67)$} \\
\hline & & $\%$ & $24.0 \%$ & $1.0 \%$ & & \\
\hline & \multirow{2}{*}{ Negative } & Count & 76 & 99 & & \\
\hline & & $\%$ & $76.0 \%$ & $99.0 \%$ & & \\
\hline \multirow{2}{*}{ Total } & & Count & 100 & 100 & & \\
\hline & & $\%$ & $100.0 \%$ & $100.0 \%$ & & \\
\hline
\end{tabular}


Table (4): Identification of HCMV (IgG) Ab from infertile and control groups by ELISA technique

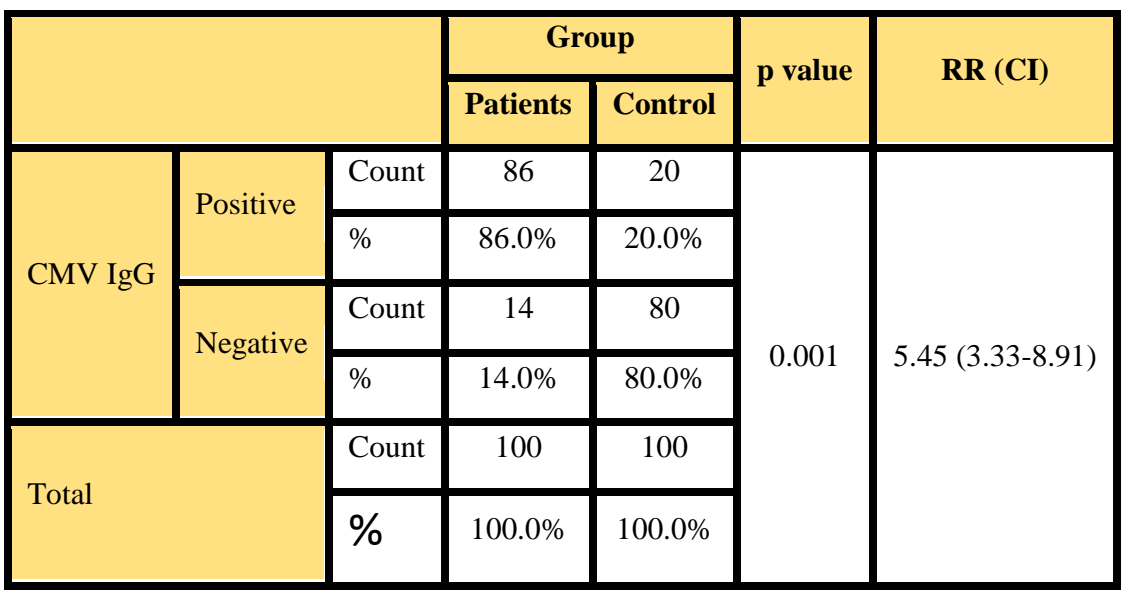

HCMV DNA was analyzed by using the Real-Time PCR method in 24 (24.0\%) of 100 semen samples of infertile males versus only $7 \%$ in fertile control group $(\mathrm{P}<0.05)$. Seminal fluid analysis for positive and negative specimens for HCMV DNA demonstrated that all positive specimens had abnormal semen parameters as seen in table (5).

Table (5): The detection of positive HCMV DNA in infertile males compared to fertile control group by RTPCR.

\begin{tabular}{|c|c|c|c|c|c|c|}
\hline & & & \multicolumn{2}{|l|}{ Group } & \multirow{2}{*}{$p$ value } & \multirow{2}{*}{ RR (CI) } \\
\hline & & & Patients & Control & & \\
\hline \multirow{4}{*}{ CMV PCR } & \multirow{2}{*}{ Positive } & Count & 24 & 7 & \multirow{6}{*}{0.001} & \multirow{6}{*}{$1.72(1.34-2.22)$} \\
\hline & & $\%$ & $24.0 \%$ & $7.0 \%$ & & \\
\hline & \multirow{2}{*}{ Negative } & Count & 76 & 93 & & \\
\hline & & $\%$ & $76.0 \%$ & $93.0 \%$ & & \\
\hline \multirow{2}{*}{\multicolumn{2}{|c|}{ Total }} & Count & 100 & 100 & & \\
\hline & & $\%$ & $100.0 \%$ & $100.0 \%$ & & \\
\hline
\end{tabular}

\section{4- Discussion}

Studies suggest that reduced semen volume, sperm motility and/or sperm morphology are all associated with individual's age, while sperm concentration is less affected (15-16). Many recent studies also reveal that sperm quality in men decreases with age $(17,18,19)$. Several study results support the finding that sperm motility decreases with advancing age $(20,21)$. Our study also found a significant reduction in sperm motility with aging.

The presence and persistence of Cytomegalo virus (CMV) in seminal fluid samples, which is a herpesvirus family member, has been always reported previously (22). In this study, HCMV seroprevalence and HCMV infection of semen was all significantly associated with male infertility. However, a lower level of CMV IgM was detected in serum than IgG reflecting a logical data showing recent infections of the tested individuals. No significant relationship between CMV DNA and seminal parameters was revealed in this study, although a trend for low motile sperms and $\alpha$-glucosidase levels was seen in the CMV-infected study group, which may indicate a modest impact of CMV infection on seminal quality, probably by affecting the function of epididymis. No association between CMV infection and a reduction in the seminal fluid parameters was reported in the previous studies (23). Our study is consistent with (24).HCMV may be infectious in the seminal fluid(25), and the virus has also been isolated from endometrial cells of humans (26), indicating a probable direct infection mechanism of endometrial cells by HCMV which is carried by sperms. Moreover, active HCMV infections may be seen in human endometrial stromal cells, (27). The anti-CMV IgG antibody prevalence, which is reported in this study, has been also found consistent with other studies reported in Turkey and other developing countries. CMV 
seroprevalence has been recorded to be (84.3\%) in patients from Nigeria, Afyon and Lagos. (28) found a $84.2 \%$ seroprevalence in infertile men.

Results of the current study disagreed with (29) who revealed $96.0 \%$ of seroprevalence of CMV IgG. In Northern Turkey, (30) reported a $1.0 \%$ and $97.3 \%$ seropositivity for anti-CMV IgM and anti-CMV IgG antibodies respectively. Seroprevalence of CMV has been also demonstrated to be age dependent in consistency with the study of (31), he recorded that $58.7 \%$ of persons aged $\geq 80$ years had positive CMV infection. An association was detected between the high CMV concentrations in ejaculate and a transient decrease in the sperm motility, and a reduction in the sperm cell concentration in seminal fluid samples of CMV infected men has been also found (32). However, no effect of CMV infection on the quality of sperms has been detected by most researchers (33).

Previously, different and contradictory studies reported the following results: $0 \%$ (culture and hybridization) among 60 males, including $30 \mathrm{CMV}$ positive versus $32.7 \%$ (PCR) among 217 males from a 92\% seropositive population who were referred for infertility(34).

Unlike (35), who found no positive specimens in seronegative patients, our results found that about $1.4 \%$ of initially seronegative people were HCMV DNA positive when the ejaculate PCR was used. This result was in agreement with that of (36), who indicated that several PCR positive results were reported in the seminal samples of seronegative males, some of whom had probable seroconvertion, while other men showed persistent seronegative results for several months. Similar results have been detected in other types of tissues (37). On the other hand, it has been shown by Eggert et al that the genital tract CMV infection in sub-fertile people is considerable, and seems to have a little role in infertility (38).

Another study by (22) reported the detection of DNA of sexually transmitted pathogen in the semen of large numbers of asymptomatic infertile men, which has been correlated with poor quality of seminal fluid (39). We may attribute this high prevalence of HCMV to the poor socioeconomic condition, poor hygienic practices and poor living conditions (40).

\section{CONFLICT OF INTERESTS}

There are no conflicts of interest.

\section{References}

[1] Wortley, P.M. Hammett, T.A. Fleming, P.L.Donor. "Insemination and human immunodeficiency virus transmission”. Obstet Gynecol;91:515-8. 1998.

[2] Dejucq, N. Jegou, B. "Viruses in the mammalian male genital tract and their effects on the reproductive system”. Microbiol Mol Biol Rev.;65:208-31. 2001.

[3] Hamdad-Daoudi, F. Petit, J. Eb, F. "Assessment of Chlamydia trachomatis infection in asymptomatic male partners of infertile couples”. J Med Microbiol.;53:985-90. 10. 2004.

[4] Guntram Bezold, , Joseph A. Politch, , Nancy B. Kiviat, Jane M. Kuypers, Hans Wolff, , and Deborah J. Anderson. "Prevalence of sexually transmissible pathogens in semen from asymptomatic male infertility patients with and without leukocytospermia". Fertil Steril.; 87(5): 1087-1097. 2007.

[5]Restrepo-Gualteros SM, Jaramillo-Barberi LE, Gonzalez-Santos M, Rodriguez-Matinez CE, Perez GF, Gutierrez MJ. "Characterization of cytomegalovirus Lung Infection in Non-HIV Infected Children Viruses";6(5):2038-2051. 2014.

[6]Chin J. "Cytomegalovirus In: Control of communicable disease manual". 17 $7^{\text {th }}$ ed. American Public Health Association: P.138. 2000.

[7]Harrison GJ. 2014Cytomegalovirus. In: Feigin and Cherry's Textbook of Pediatric Infectious Diseases, $7^{\text {th }}$ ed. Elsevier Saunders. Philadelphia:p.1969.

[8]Crugh T \& Khanna R.’'Immunobiology of human cytomegalovirus: from bench to be side”. Clinical microbiology reviews;22(1):76-98. 2009.

[9] Mocarski ES, Jr, Shenk T. Pass RF.” Cytomegaloviruses. In: Knipe DM, Howley PM, editors. Fieldes”' Virology. 5. Lippincott Williams \& Wilkins; Philadelphia.p.2702-2772. 2007.

[10] Diafouka, F., Foulongne, V., Hauhouot-Attoungbre, M. L., Monnet, D. \& Segondy, M.”Cytomegalovirus DNA in semen of men seeking fertility evaluation in Abidjan, Cote d'Ivoire". Eur. J. Clin. Microbiol. Infect. Dis; 26, 295-296. 2007.

[11] Eggert-Kruse, W., Reuland, M., Johannsen, W., Strowitzki, T. \& Schlehofer, J. R.” Cytomegalovirus (CMV) infection—related to male and/or female infertility factors?" Ferti l. Steril .; 91, 67-82. 2009. 
[12] Aynaud O, Poveda JD, Huynh B, Guillemotonia A, Barrasso R. "Frequency of herpes simplex virus, cytomegalovirus and human papillomavirus DNA in semen”. Int J STD AIDS. ;13:547-50. 2002.

[13]A wqati NA, M Ali MM, Al-Ward NJ, A Majeed FA, Salman K, Mahdi Al-Alak ."causes and differentials of childhood mortality in Iraq". BMC pediatrics , 9:40 doi:10. 1186/1471-2431-9-40. 2009.

[14] World Health Organization (WHO). Laboratory manual for the examination of human semen and spermcervical mucus interaction. 3rd ed. Cambridge, England: Cambridge University Press. 1992.

[15] Brawer MK. "Testosterone Replacement in Men with Andropause: An Overview”. Rev Urol. ;6 (Suppl.):S9S15. 2004.

[16] Eskenazi B, Wyrobek AJ, Sloter E, Kidd SA, Moore L, Young S, Moore D."The association of age and semen quality in healthy men”. Hum Reprod. ;18:447-454. 2003.

[17] Girsh E, Katz N, Genkin L, Girtler O, Bocker J, Bezdin S, Barr I."Male age influences oocyte-donor program results". J Assist Reprod Genet. ;25:137-143. 2008.

[18] de la Rochebrochard E, Thonneau P. "Paternal age and maternal age are risk factors for miscarriage; results of a multicentre European study”. Hum Reprod. ;17:1649-1656. 2002.

[19] de Almeida Ferreira Braga DP, Setti AS, Figueira RC, Nichi M, Martinhago CD, Iaconelli A Jr, "Sperm organelle morphologic abnormalities: contributing factors and effects on intracytoplasmic sperm injection cycles outcomes". Urology;78:786-791. 2011.

[20]Auger J, Kunstmann JM, Czyglik F, Jouannet P. 1995."Decline in semen quality among fertile men in Paris during the past 20 years". N Engl J Med. ;332:281-285.

[21] Fisch H, Goluboff ET, Olson JH, Feldshuh J, Broder SJ, Barad DH. "Semen analyses in 1,283 men from the United States over a 25-year period: no decline in quality”. Fertil Steril. ;65:1009-1014. 1996.

[22] Bezold, G. Schuster-Grusser, A. Lange, M. Gall, H. Wolff, H. Peter, R.U.'Prevalence of human herpesvirus types 1-8 in the semen of infertility patients and correlation with semen parameters". Fertil Steril;76:416-8. 2001.

[23] Cengiz, T. Aydoganli, L. Baykam, M. Mungan, N.A. Tuncbilek, E. Dincer, M. Yakupoglu, K. Akalin, Z."Chlamydial infections and male infertility". Int Urol Nephrol ;29:687-693. 1997.

[24]Francisse, S. ;Revelard, P. ; De Maertelaer, V. ; Strebelle, E. ; Englert, Y. ; Liesnard, C."Human Cytomegalovirus Seroprevalence and Risk of Seroconversion in a Fertility Clinic Population".Inst. Inter. Res. Hum Bio. Mol.; 114 1: 285-291. 2009.

[25]Lisco A.; Munawwar A.; Introini A.; Vanpouille C.; Saba E.” Semen of HIV-1-infected individuals: local shedding of herpesviruses and reprogrammed cytokine network". J Infect Dis. ; 205:97 105. 2012.

[26]Frank, T.; Himebaugh, K.; and Wilson, M. "Granulomatous endometritis associated with histologically occult cytomegalovirus in a healthy patient”. Am J Surg Pathol. ; 16:716 720. 1992.

[27]Naumenko, V.;Tyulenev, Y.; Yakovenko, S.; Kurilo, L.; Shileyko, L. "Detection of human cytomegalovirus in motile spermatozoa and spermatogenic cells in testis organotypic culture”. 2011.

[28] Okwori AEJ, Olabode AO, Emumwen EG, Echeonwu GO, Lugos MO, Okpe ES, Okopi JA, Adetunji JA. "Sero-Epidemiological Survey of Human Cytomegalovirus Infection among Expectant Mothers in Bida, Nigeria”. The Internet Journal of Infectious Diseases. ;7(1). 2009.

[29] Akinbami AA, Akanmu AS, Adeyemo TA, Wright KO, Dada MO, Dosunmu AO. "Cytomegalovirus antibodies among healthy blood donors at Lagos University Teaching Hospital". South African Medical Journal. ;99(7):528-530. 2009.

[30]Uyar Y, Balci A, Akcali A, Cabar C. "Prevalence of rubella and cytomegalovirus antibodies among pregnant women in northern Turkey". New Microbiologia. ;31(4):451-455. 2008.

[31] Dollard S, Grosse S, Ross D. "New estimates of the prevalence of neurological and sensory sequelae and mortality associated with congenital cytomegalovirus infection". Review of Medical Virology.;17(5):355-363. 2007.

[32]Wu KH, Zhou QK, Huang JH, Lai RQ, Lin FH, Li B, Zhang CB, Zhou WN, Zhu ZP.'Infection of cytomegalovirus and herpes simplex virus and morphology of the infected spermatogenic cells in infertile men”. Zhonghua Nan Ke Xue. ;13:1075-1079. 2007.

[33]Klimova RR, Chichev EV, Naumenko VA, Gadzhieva ZS, Tsibisov AS, Adieva AA, L'vov DK, Kurilo LF, Shileiko LV, Ostroumova TV, Sorokina TM, Gavrilov IuA, Levchuk TN, Iakovenko SA, Vasil'eva SG, Voznesenskaia IuV, Simonenko Eiu, Kushch AA, Sukhikh GT. "Herpes simplex virus and cytomegalovirus in male ejaculate: herpes simplex virus is more frequently encountered in idiopathic infertility and correlates with the reduction in sperm parameters". Vopr virusol. ;55:27-31. 2010. 
[34]Shen, C.Y., Chang, S.F., Yang, S.L., Wu, C.W., Yang, Y.S., Ho, H.N. and Huang, E.S. "Cytomegalovirus is present in semen from a population of men seeking fertility evaluation".J. Infect. Dis. ; 169, 222-223. 1994.

[35] Levy, R., Najioullah, F., Keppi, B., Thouvenot, D., Bosshard, S., Lornage, J., Lina, B., Guerin, J.F. and Aymard, M. "Detection of cytomegalovirus in semen from population of men seeking infertility evaluation”. Fertil. Steril. ;68, 820-825. 1997.

[36]Witz, C.A., Duan, Y., Burns, W.N., Atherton, S.S. and Schenken, R.S.” Is there a risk of cytomegalovirus transmission during in vitro fertilization with donated oocytes?" Fertil. Steril. ; 71, 302-307. 1999.

[37]Larson, S., Soderberg-Naucler, C., Wang, F.Z. and Moller, E."Cytomegalovirus DNA can be detected in peripheral blood mononuclear cells from all seropositive and most seronegative healthy blood donors over time". Transfusion;38, 271-278. 1998.

[38]Eggert-Kruse W, Reuland M, Johannsen W, Strowitzki T, Schlehofer JR.” Cytomegalovirus (CMV) infection-Related to male and/or female infertility factors?” Fertil Steril. ;91:67-82. doi: 10.1016/j.fertnstert;11.014. 2009.

[39]Bezold G, Politch JA, Kiviat NB, Kuypers JM, Wolff H, Anderson DJ.”Prevalence of sexually transmissible pathogens in semen from asymptomatic male infertility patients with and without leukocytospermia". Fertil Steril. 2007;87:1087-1097. doi: 10.1016/j.fertnstert. 08.109. 2006.

[40]Jawetz E, Melinck J, Adberg EA, Broks GO, Butel JS, Ornston NL. "Medical microbiology. 23. Applenton and Lange: Norwalk", USA. 2004.

\section{العلاقة بين الفيروسات المضخمه للخلايا التي تصيب القناة التناسلية عند الرجال مع الأكور العقيمين

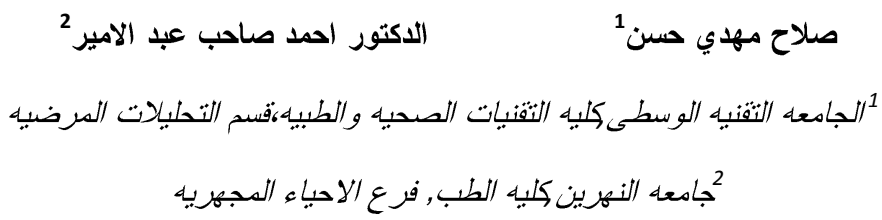 \\ drnihadkhalawe@gmail.com}

الخلاصه

الخلفية: الفيروس المضخم للخلايا واسع الانتشار بين الناس وله القدره على الانتقال جنسيا. لها تاثير على عملية تكوين الحيامن والانتقال بواسطة الخلايا المنويه , اذ لا نوجد تفاصيل كافيه لنتخيصها لكون نسبة وجودها في السائل المنوي قليله. الهـف: للتحري عن الاصابات الفيروسيه المشتركه في الجهاز التناسلي الذكري للذكور العقيمين وعلافتها مع حالات العقم في الذكور طرق العمل: تقنية الاليز ا وتفاعل البلمره المتسلسل استخدمت لتشخيص . . المشخصين والمصابين بالعق.عن طريق التحري عن مضادات

النتائج: . . 1 عينة سائل منوي ومصل استحصلت من الذكور المصابين بحالات عقم بالاضافه الى مجموعة السيطره خلال فترة 1 اثنهرمن

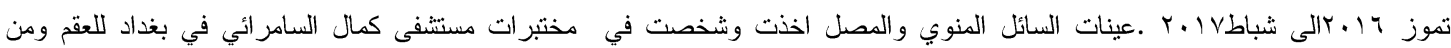

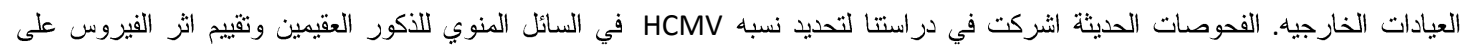

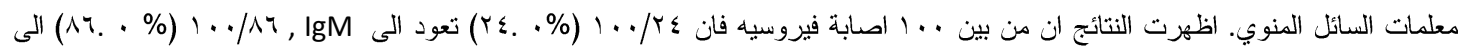

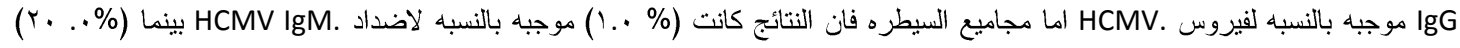
لاضداد HSMV IgG باستعمال طريقة الاليز ا.

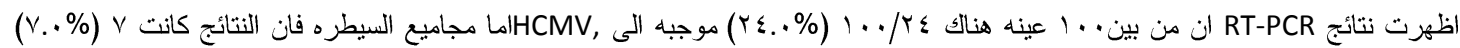
HCMV. موجبه بالنسبه الاستتتاجات: باستخدام تقنيات حساسه للتشخيص ،تمكنا من تحديد نسب عاليه للاصابات الفيروسيه المساهمه بالامر اض المنتقله جنسيا في السائل المنوي والمصل للذكور العقيمين. الكلمات الدالة: الفيروسات، الذكور العقيمين، الجهاز التناسلي الذكري. 